\title{
Alcohol and pH Detectors Based Internet of Thing for Hand Sanitizer
}

\author{
$1^{\text {st }}$ Geovani Rahmad Illahi \\ Dept. Electrical Engineering \\ Universitas Sebelas Maret \\ Surakarta, Indonesia \\ geovani.ri2001@student.uns.ac.id \\ $4^{\text {th }}$ Yuki Martha Anggraini \\ Dept. Chemical Engineering \\ Universitas Sebelas Maret \\ Surakarta, Indonesia \\ yukimarthaa@student.uns.ac.id
}

\author{
$2^{\text {nd }}$ Hayyan Yusuf \\ Dept. Electrical Engineering \\ Universitas Sebelas Maret \\ Surakarta, Indonesia \\ hayyanyusuf@student.uns.ac.id \\ $5^{\text {th }}$ Hibatul Wafi Ah Fahrudin \\ Dept. Mediciness \\ Universitas Sebelas Maret \\ Surakarta, Indonesia \\ hibatulwafiahf@student.uns.ac.id
}

\author{
$3^{\text {rd }}$ Diah Anggi Munika \\ Dept. Chemical Engineering \\ Universitas Sebelas Maret \\ Surakarta, Indonesia \\ diahanggi@student.uns.ac.id \\ $6^{\text {th }}$ Feri Adriyanto*) \\ Dept. Electrical Engineering \\ Universitas Sebelas Maret \\ Surakarta, Indnesia \\ feri.adriyanto@staff.uns.ac.id \\ *Corresponding author
}

\begin{abstract}
Alcohol and pH levels in hand sanitizer are two things that need to be considered. The amount of alcohol content affects the level of effectiveness in killing germs, while the $\mathrm{pH}$ level is a factor that indicates whether the liquid is safe for human skin or not. HANDSIOT is a device to measure alcohol levels and pH in hand sanitizers. HANDSIOT is operated by testing the hand sanitizer liquid in the liquid container at the bottom. This device is made to be able to take measurements effectively and can monitor the measurement results in real-time using a smartphone. Gas chromatography and electrolysis methods were implemented using the MQ-3 gas sensor and the SEN0161 pH sensor. The gas chromatography method is used as a method of measuring alcohol content based on the evaporation of the alcohol. While the electrolysis method is used to measure the pH degree by measuring the amount of current flowing using two electrodes. In testing the accuracy of this tool by comparing the readings on the tool with an alcohol meter and also a pH sensor that is already available on the market
\end{abstract}

Keywords—hand sanitizer, alcohol level, measurement, pH degree

\section{INTRODUCTION}

The existence of a new pathogen, bacteria, or virus is a challenge for the world of health. The characteristic of the virus which easily mutates so it spreads easily is no exception for the Sars-CoV-2 virus or known as COVID-19 [1]. The World Health Organization (WHO) on January 30, 2020, has established COVID-19 as a Public Health Emergency of International Concern (KKMMD/PHEIC) by the report from Wuhan, other provinces in China and several countries whose residents had traveled to Wuhan City, they had pneumonia The Sars-CoV-2 virus is still a large family of coronaviruses that mainly cause acute respiratory disorders and can even causes death [2]. According to WHO (2020), the Sars-CoV-2 virus can attack anyone from infants to the elderly, pregnant women, and even breastfeeding mothers. The virus can be transmitted directly through the air (airborne and droplet), especially when people are coughing, sneezing, talking in closed rooms with poor ventilation, and can also be spread through feces or urine. In addition, this virus can transmit indirectly by staying on surfaces and objects for hours adjusting to temperature and humidity. One way to prevent the spread of virus can be done by cleaning hands with soap and water, antiseptic soap, alcohol-based hand sanitizer, or antiseptic hand soap [3].

COVID-19 pandemic has made people have a Clean and Healthy Lifestyle, make it into a new habit, one of those is cleaning their hands. Ideally, wash hands with soap is done for at least 15-30 seconds. The alternative is using hand sanitizer. Hand sanitizer is a product that contains a minimum of $60-95 \%$ ethanol alcohol or $70 \%$ isopropanol, which is used on hands to kill microorganisms and/or temporarily suppress the growth of microorganisms. It is necessary to be knowledgeable about the $\mathrm{pH}$ level so it doesn't damage human skin cells by levels of $\mathrm{pH}$ 4.5-5.5 for women and ph 4-5.5 for men [3].

The alcohol content in the hand sanitizer can be measured by various methods. To calculate the alcohol content in a liquid is by calculating the percentage of alcohol to the solvent. Existing methods for measuring alcohol content include Gas Chromatography (GC), High-Performance Liquid Chromatography (HPLC) analysis, enzyme methods, and cyclic voltammetry methods. In this study, the method is used for measuring alcohol content is the cyclic voltammetry method.

Meanwhile to calculate the $\mathrm{pH}$ level, can use the $\mathrm{pH}$ sensor as the easiest way. There have been many studies that use $\mathrm{pH}$ sensors. One of the most frequently used types is the SKU type SEN0161. Based on research [4]. SKU type $\mathrm{pH}$ sensor SEN0161 has an accuracy rate of $98.86 \%$. Based on this research, it can be proven that the SKU SEN0161 type pH sensor has a high level of accuracy and is suitable for use in this research.

The device was made this time is a combination of two types of measurement methods; Cyclic Voltammetry and SKU SEN0161. By using these two measurement methods and the integrated data with the Internet of Things (IoT). This device is expected to be able to meet the need in determining alcohol levels and $\mathrm{pH}$ degrees on hand sanitizers so they can be safe and effective. 


\section{BACKGROUNDS}

\section{A. Previous Studies}

During the COVID-19 pandemic, many people are starting to understand the importance of hand hygiene. Hand hygiene is done as a way to suppress the spread of the COVID-19 virus. One of the most common ways to clean hands is using hand sanitizer. The number of hand sanitizers on the market makes people have to choose a hand sanitizer that is safe and effective in killing germs. There are many studies in the manufacture of hand sanitizers such as the research conducted by Ningsih (2016) entitled "Formulasi Dan Uji Aktivitas Antibakteri Gel Pembersih Tangan Ekstrak Etanol Daun Kembang Bulan" [5]. To increase efficiency in testing hand sanitizers, a more practical and simple tool is needed. Until now, there is still no tool that can practically test hand sanitizer quickly and precisely.

\section{B. Hand Sanitizer}

The method commonly used to clean hands is using a hand sanitizer because it is easy and comfortable on human skin. However, not all hand sanitizers are effective in killing germs. There is the main content in hand sanitizer which useful for killing germs that is the alcohol, the alcohol content which is effective for killing germs based on research by Radji (2007) [6].

\section{Internet of Things}

During the industrial revolution 4.0, used a lot of automation systems. Making the use of the internet as a connection between one to another is very important. By using the IoT all objects can be connected continuously, making it possible to monitor and manage the system based on the latest data obtained in real-time. In theory, the IoT concept is quite simple which refers to three important elements: physical components with IoT modules, internet connections, and cloud data as database storage [7].

\section{TECHNICAL APPROACH}

A. Schematic and Design

The main components consist of:

1. MQ-3 Alcohol sensor as a module to measure alcohol content

2. SEN0161 $\mathrm{pH}$ sensor as $\mathrm{pH}$ degree measurement

3. Regulator LM317 as a DC step down module to change from $12 \mathrm{~V}$ input to $5 \mathrm{~V}$ output

4. LCD monitor as a display of measurement results.

5. DC jack input to plug the connector from power supply.

6. Microcontroller ESP32 as a processor to convert ADC signal from sensor to $\mathrm{pH}$ degree and alcohol content value

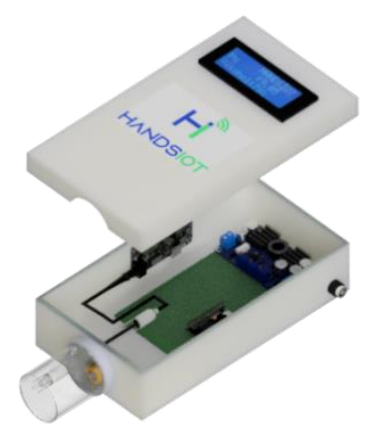

Fig. 1 Design of Detectors Alcohol Levels and $\mathrm{Ph}$ Degrees

\section{B. Measurement system}

The measurement system is processed using the esp32 microcontroller. The ADC signal with a value range of 0-4095 (12 bits) obtained from the sensor module is then processed using linear regression analysis to obtain a linear equation so it can change the $\mathrm{ADC}$ value to the final value.

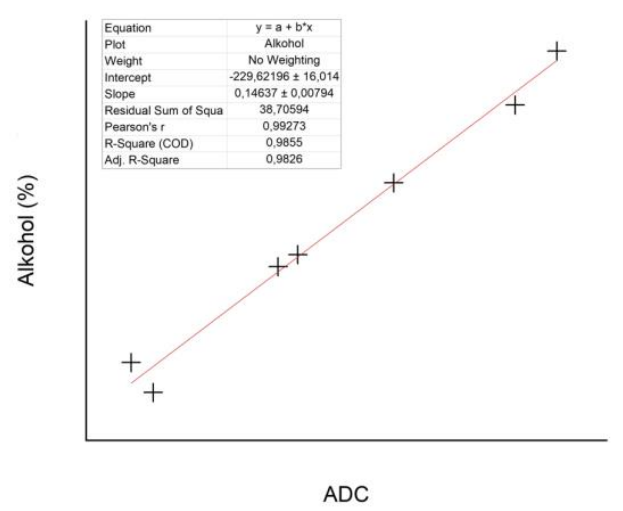

Fig. 2 Linear Regression Graph From Alcohol Measurements

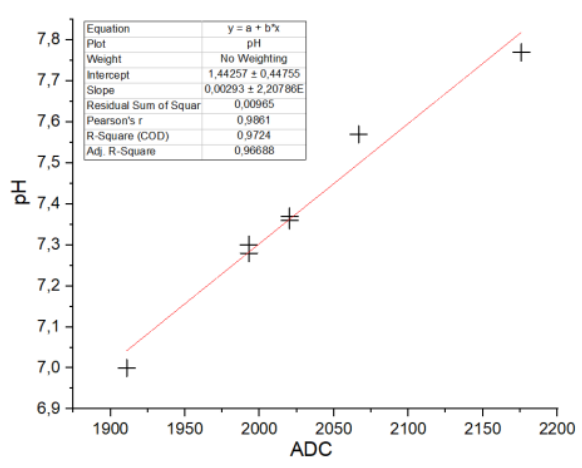

Fig. 3 Linear Regression Graph From pH Measurements

In the measuring system, there is two main stages:

1. Measurement of $\mathrm{pH}$ degrees using the SEN0161 $\mathrm{pH}$ sensor which utilizes the principle of electrolysis on carbon rods.

2. The alcohol vapor produced by the gas chromatography was measured using an alcohol 
sensor MQ-3.

\section{Monitoring System}

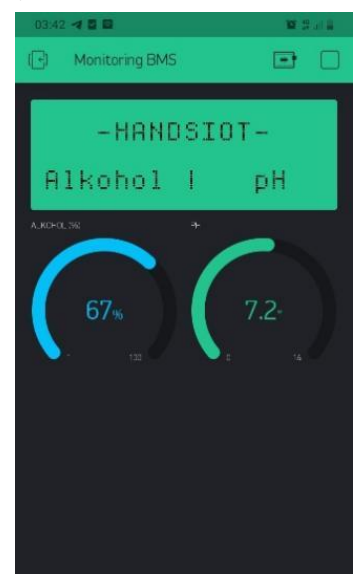

Fig 4. User Interface on Smartphone

There are two ways to read the measurement results, first by using the LCD screen and the second by using an application on a smartphone. When the hand sanitizer has been placed in the container, the reading of the measurement results can be directly read in real-time. To be able to connect to the smartphone, this device is connected to internet using the Node MCU. The readings on the smartphone screen are displayed in graphic form so it is easy to read.

\section{SYSTEM FUNCTION}

\section{A. Internet of Things}

The Internet of Things is a technological revolution, which represents the future of computing and communications. The purpose of IoT is to expand the benefits of the internet by facilitating the transfer of information between objects remotely in real time, it allows every connected object to collaborate or even act according to the latest information obtained. The use of IoT in HANDSIOT makes it easier for users when measuring the content in alcohol because the measurement results in the form of $\mathrm{pH}$ value data and alcohol content will be sent to smartphone which connected to the internet, so they will form a measurement data bank. then the data collected can be used as reference material in the future.
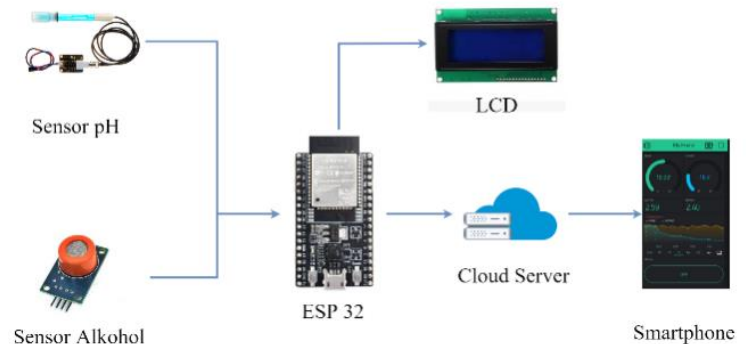

Fig 5. Architecture of System

B. Components of The Systems

1. ESP 32 Microcontroller

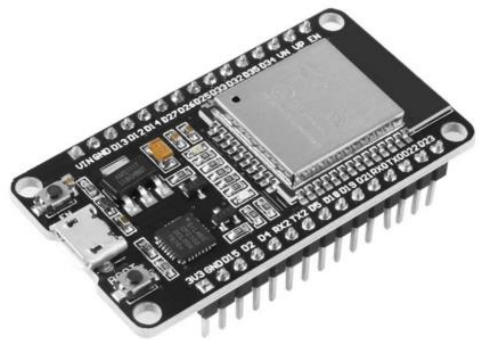

Fig 6. ESP 32 Microcontroller

This ESP32 is an IoT module which functions as an open source electronic circuit controller so it can be programmed as desired. Because there is already a WiFi module in it, it can connect several components remotely using the internet[8]. On the ESP32 there are several ADC pins which able to read analog signals from the sensor. The use of ESP32 on HANDSIOT is as a data processing system from sensors to final values. In addition, the WIFI module on the ESP32 is also used as a device to connect the device to the internet.

2. MQ-3 Alcohol Sensor

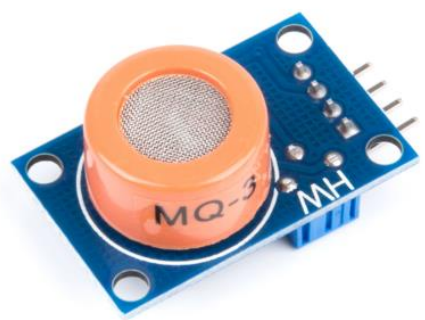

Fig 7. MQ-3 Alcohol Sensor

Alcohol or ethanol is a substance which is very easy to evaporate. Units of substances which evaporate into the air are declared in ppm (parts per million). To measure alcohol concentration based on evaporation, a sensitive sensor is needed to detect alcohol content. The output of the sensor is an analog voltage which is proportional to the alcohol content. ADC signal reading with a voltage of 0 volts -3.3 volts can be used to get the alcohol value from the MQ-3 sensor,

3. $\mathrm{pH}$ Meter SEN0161

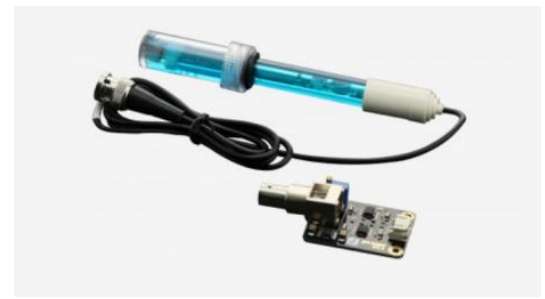

Fig 8. SEN0161 pH Sensor

A $\mathrm{pH}$ sensor is a module used to measure the quality or alkalinity of a liquid. $\mathrm{pH}$ meter consists of an electrode connected to an electronic device to measure and display the $\mathrm{pH}$ value[9]. In this sensor, 
the sensor element is coated with a silver chloride solution in the center $(\mathrm{Ag}-\mathrm{AgCl})$. The $\mathrm{pH}$ meter in this research was used to measure the $\mathrm{pH}$ level of the liquid hand sanitizer. With a $\mathrm{pH}$ measurement range of $0-14$.

4. Electrode

Analysis of chemical compounds using electrical energy can be done by electrochemical techniques. In electrochemistry, there are main components which are most needed, namely working electrodes, auxiliary electrodes, and reference electrodes. Carbon (C) electrodes are considered effective as working and auxiliary electrodes because they are stable, do not react with analytes, are affordable and easy to obtain. While $\mathrm{Ag} / \mathrm{AgCl}$ is generally used as a reference electrode. In an electrochemical system, there is an oxidation reaction at the anode and reduction at the cathode. The electrons will be carried by the cations on the working electrode to the auxiliary electrode so as to produce a measurable current.

\section{RESULTS AND DISCUSION}

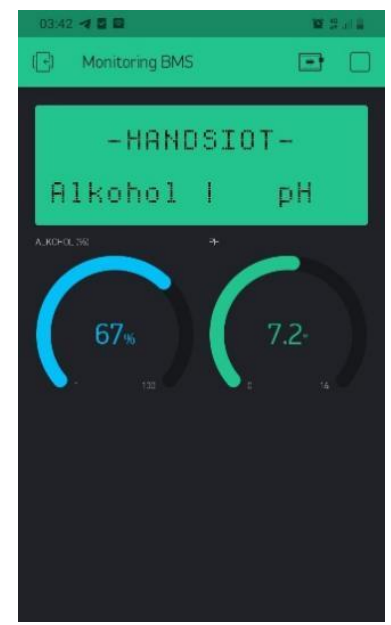

Fig 9. User Interface

The measurement results are read by a device, which allows users to view experimental data through the Blynk application as can be seen in Figure 9. By using a system which is integrated with the internet. Then this device can send data in real-time to the user as long as the user has internet access. Internet of Things (IoT) applications can be utilized for two-way communication [7]. However, this device only uses a one-way system where data from the device is sent directly.

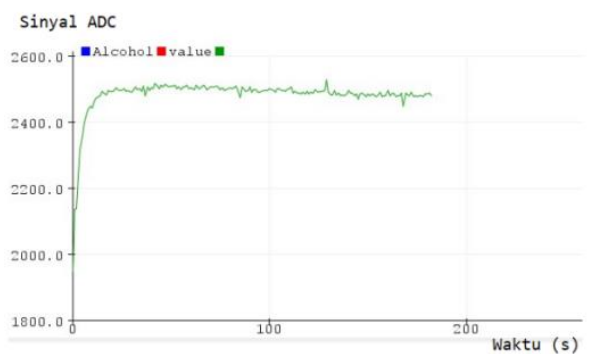

Fig 10. ADC Signal Reading

In reading alcohol and $\mathrm{pH}$ levels. There is the time required for the sensor to get the stable results. Figure 10, which is an experiment to read alcohol gas. It takes approximately 30 seconds for the sensor reading graph until it is stable. If the measurements are less than 30 seconds, the results will be unstable.

Table 1. Data Result of Accuracy Test

\begin{tabular}{|c|c|c|c|c|c|c|}
\hline No & $\begin{array}{c}\text { Alcohol } \\
(\%)\end{array}$ & $\mathrm{pH}$ & $\begin{array}{c}\text { Alcohol Detected } \\
\text { by HANDSIOT } \\
(\%)\end{array}$ & $\begin{array}{c}\text { pH Detected by } \\
\text { HANDSIOT }\end{array}$ & $\begin{array}{c}\text { Accuracy of } \\
\text { Alcohol } \\
\text { Reading by } \\
\text { HANDSIOT } \\
(\%)\end{array}$ & $\begin{array}{c}\text { Accuracy of } \\
\text { Alcohol } \\
\text { Reading by } \\
\text { HANDSIOT } \\
(\%)\end{array}$ \\
\hline 1 & 30 & 7,5 & 38 & 7,3 & 78 & 97 \\
\hline 2 & 43 & 7,2 & 43 & 7,4 & 100 & 97 \\
\hline 3 & 55 & 7,4 & 59 & 7,4 & 93 & 100 \\
\hline 4 & 60 & 7,1 & 61 & 7 & 98 & 98 \\
\hline 5 & 74 & 7,6 & 73 & 7,57 & 98 & 99 \\
\hline 6 & 85 & 7,7 & 86 & 7,97 & 98 & 9,6 \\
\hline 7 & 97 & 7,1 & 95 & 7,30 & 9,7 & 97 \\
\hline
\end{tabular}

In this experiment, seven different samples were tested according to the data in table 1 . It was found that the accuracy of the $\mathrm{pH}$ sensor was up to $96 \%$ in all samples. if the alcohol content is less than $40 \%$, the reading is relatively less accurate. Therefore the use of this device is recommended for alcohol with level of $40 \%$ or up.

Table 2. Data Result of Alcohol and $\mathrm{pH}$ Content Test on Several Brands

\begin{tabular}{|c|c|c|}
\hline Brands & Alcohol $(\%)$ & $\mathrm{pH}$ \\
\hline A & 71 & 7.8 \\
\hline B & 74 & 7.9 \\
\hline C & 79 & 7.9 \\
\hline D & 77 & 8 \\
\hline E & 73 & 7.7 \\
\hline F & 63 & 7.5 \\
\hline
\end{tabular}

Based on testing from several brands of hand sanitizers sold in the market. Regarding the level above, the effectiveness of alcohol in killing germs is $60 \%$ and the level of safety for the $\mathrm{pH}$ value for human skin is 5.5-8.0. Based on the data contained in table 2 , most of the hand sanitizer brands were effective and safe for use in killing germs.

\section{CONLUSION}

The device for detecting alcohol and pH levels in hand sanitizers, which are integrated with Android Smartphones via the IoT is expected to be used as a solution for implementing a clean and healthy lifestyle in the pandemic era. From the health aspect, it can be used as a device that can detect alcohol and $\mathrm{pH}$ levels in hand sanitizers so it is effective and safe to kill germs and viruses and does not damage the skin barrier. From the aspect of science and technology, it is a form of digitizing data collection on alcohol and $\mathrm{pH}$ level in hand sanitizers because it is based on the IoT so people have no difficulties in choosing the righthand sanitizer. The HANDSIOT can be developed further because it has several benefits, such as:

1. Increase public awareness in choosing hand sanitizer.

2. Make it easier for the public to know the quality of hand sanitizer. 
3. Increase public awareness of the importance of using hand sanitizers in suppressing the spread of the COVID-19 virus.

4. it is cheaper than any conventional measurement

5. The accuracy rate is above $90 \%$ so that the measurement data can be trusted

\section{REFERENCES}

[1] A. P. Golin, D. Choi, and A. Ghahary, "Hand sanitizers: A review of ingredients, mechanisms of action, modes of delivery, and efficacy against coronaviruses," Am. J. Infect. Control, vol. 48, no. 9, pp. 1062-1067, 2020, doi: 10.1016/j.ajic.2020.06.182.

[2] Kemenkes RI, "Pedoman Pencegahan dan Pengendalian Coronavirus Disease (COVID-19)," Germas, pp. 0-115, 2020.

[3] C. Prakash, P. Bhargave, S. Tiwari, B. Majumdar, and R. K. Bhargava, "Skin surface $\mathrm{pH}$ in acne," J. Clin. Aesthet. Dermatol., vol. 10, no. 7, pp. 33-39, 2017.

[4] I. A. Rozaq, N. Yulita, D. Setyaningsih, and K. Kunci, "Karakterisasi dan kalibarasi sensor ph menggunakan arduino uno 12," Sendi_U, pp. 978-979, 2018.

[5] W. Ningsih, F. Firmansyah, and S. Anggraini, "Formulasi Dan Uji Aktivitas Antibakteri Gel Pembersih Tangan Ekstrak Etanol Daun Kembang Bulan (Tithonia Diversifolia (Hemsley) a. Gray)," J. Ilm. Farm., vol. 12, no. 2, pp. 53-61, 2016, doi: 10.20885/jif.vol12.iss2.art6.

[6] M. Radji and H. Suryadi, "Uji Efektivitas Antimikroba Beberapa Merek Dagang Pembersih Tangan Antiseptik," Pharm. Sci. Res., vol. 4, no. 1, pp. 1-6, 2007, doi: 10.7454/psr.v4i1.3408.

[7] Y. Efendi, "Internet Of Things (Iot) Sistem Pengendalian Lampu Menggunakan Raspberry Pi Berbasis Mobile," J. Ilm. Ilmu Komput., vol. 4, no. 2, pp. 21-27, 2018, doi: 10.35329/jiik.v4i2.41.

[8] A. Al-Fuqaha, M. Guizani, M. Mohammadi, M. Aledhari, and M. Ayyash, "Internet of Things: A Survey on Enabling Technologies, Protocols, and Applications," IEEE Commun. Surv. Tutorials, vol. 17, no. 4, pp. 2347-2376, 2015, doi: 10.1109/COMST.2015.2444095.

[9] D. G. A. Wafa, "Rancang Bangun Sistem Pengendalian pH Pada Proses Tranesterifikasi Dalam Mini Plant Biodiesel Di Workshop Instrumentasi," p. 115, 2017, [Online]. Available: http://repository.its.ac.id/47303/. 